\title{
Effects of Bacillus thuringiensis Cry Toxin, Propolis Extracts and Silver Nanoparticles Synthesized by Soil Fungus (Fusarium oxysporum) Against Two Species of Tetranychus spp. (Acari:Tetranychidae) Sabrien A. Omar ${ }^{1}$; I. A. Elsayed ${ }^{2}$; Amal E. Marouf ${ }^{3}$ and D. H. Dawood ${ }^{4}$ ${ }^{1}$ Dept of Microbiol and ${ }^{4}$ Dept of Chem., Fac of Agri., Mansoura Univ., Mansoura, Egypt ${ }^{2}$ Dept of Microbiol., Soil, Water and Environm. Institute, Agric. Research Center, Giza, Egypt. ${ }^{3}$ Plant Protectection Institute, Agric. Res. Center, Giza, Egypt.
}

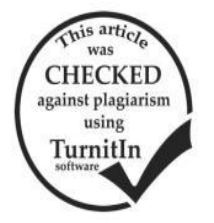

\section{ABSTRACT}

Development of new biostrategies for pest control represents a major eco-friendly achievement. The use of micoorganisms represents one of these biostratigies. Bacillus thuringiensis d-endotoxins are recognized safe and economic biological insecticidal proteins. Green nanotechnology is one of the most promisg approches in this field. Our study, demonstrated that $B$. thuringiensis (4QSTR1) produced cry proteins, which appeared as stained crystals. The Coomassie Brilliant Blue stain allowed a quick and high productivity evaluation of $B$. thuringiensis (4QSTR1). Synthesized silver nanoparticles by using Fusarium oxysporum (Fo-AgNPs) were used. Also, the protein crystals and endospores of Bacillus thuringiensis were separated. The bioinsecticidal effect of synthesized Fo-AgNPs, Bacillus thuringiensis (Bt) and propolis extracts (ethanolic extract (EEP) and water extract (WEP)) against Tetranychus urticae Koch and Tetranychus cinnabarinus (Boisduval) was evaluated. Bioassays results showed that the insecticidal efficacy $\left(\mathrm{LC}_{50}\right.$ and $\left.\mathrm{LC}_{90}\right)$ of $F o$-AgNPs were more effective than propolis extracts and $\mathrm{Bt}$ against the two species of Tetranychus. The $\mathrm{LC}_{50}$ value for Fo-AgNPs, WEP, EEP and Bt against T. urticae were 45, 10234, 12755 and 14972, respectively and against $T$. cinnabarinus were 37, 13579, 15881 and 17003, respectively. More than $100 \%$ toxicity index was recorded by Fo-AgNPs with two species of Tetranychus. The total mortality percentage of two species of Tetranychus was more affected by $F o-A g-N P s$ at the lowest dose (10ppm). Whereas, the propolis extracts and Bt were more effective at the highest dose $\left(20 \times 10^{3} \mathrm{ppm}\right)$. It is clear that silver nanoparticles synsthized by soil fungus (Fusarium oxysporum) have a strong insecticidal effect.

Keywords: Biological control -Fusarium oxysporum - Silver nanoparticles - Crystal toxins - Propolis - red spider mites.

\section{INTRODUCTION}

The red spider mites, Tetranychus spp. (Acari: Tetranychidae) is one of pests that has a major impact on cultivated strawberries around the world. Tetranychus spp. is considered a major pest decreasing plant growth and yield on different agricultural crops, including bean plants (Farouk \& Osman 2009). The mites has been reported to attack about 1200 species of plants and over150 host plants are of economic value (Zhang, 2003)

Developing countries as in Africa, South America and Asia are suffering from the hazardous routinely utilization of agro-chemicals such as chemical insecticides which have an unexpectedly high ecological cost, contributing to global pollution, unfavorable climate change and loss of microbial biodiversity (Vance, 1998). Pesticides are classified as being extremely or highly hazardous by FAO and WHO. The most promising strategy for sustainable agriculture reaches to substitute hazardous agrochemicals (mineral fertilizers, pesticides) with eco-friendly preparations which could increase the protection from biotic such as pathogens and pests (Yang et al., 2009).

Propolis is the dark-brown or black sticky plant derived 'glue' found around wounds and buds of plants. It is used by bees for sealing, lining, strengthening of their hives (Banskota et al., 2001). Various studies demonstrated the antibacterial and antifungal of propolis due to its high content of total phenols and flavonoids. Few studies had been examined the insecticidal properties of propolis. Zewda and Legessa (2016) Evaluate the insecticidal effect of propolis against larvae of lesser wax moth Achroia grisell concluded that ethanol extract of propolis at higher concentrations is a powerful contact toxicant against young wax moth larvae.

The microorganisms have taken an excellent position among the options that used to control pests with high specific toxicity and without the use of chemicals applied in agroecosystems (Schünemann et al. 2014).

Bacillus thuringiensis $(B t)$ is a unique bacterium in that it widely spread in soils throughout the world (Huang et al., 2001). Bacillus thuringiensis is spore-forming bacterium that produces insecticidal crystal protein toxins during sporulation. Bacillus thuringiensis d-endotoxins are recognized safe biological insecticidal proteins Thomas et al.,(2000). This bacterium represents an economic source and safe for human health (Siegel, 2001), in addition, the use of Bacillus thuringiensis for the production of biopesticides, is likely to be a promising achievement associated with eco-friendly aspects (Frankenhuyzen, 2009).

Nanotechnology has become a promising new strategy for environmental clean-up technologies that could provide economic solutions for some of the most challenging environmental problems (Chinnamuthu and Murugesa Boopathi, 2009). Nanoparticles can be used to produce new insecticides (Owolade et al., 2008). The insecticidal effect of the biosynthesized silver nanoparticles against the larvae and adult of Callosobruchus maculates on cowpea seed were examined (Rouhani et al. 2012) and also, against Anopheles stephansi, Culex quinquefaciatus and Aedes aegypti (larvae and pupae) (Soni and Prakash 2013 and Banu et al., 2014).

The use of microorganisms in the synthesis of nanoparticles is called a green nanobiotechnology which does not produce toxic wastes during the synthesis process. Some microorganisms, including bacteria, yeast and filamentous fungi could be used as nanofactories (Fortin and Beveridge 2000). Fungi have several advantages in the production of nanoparticles including, high growth rate, high production of specific enzymes and easy handling in large scale (Vahabi et al., 2011). Fusarium oxysporum represents an interesting example for biosynthesis of silver 
nanoparticles (Ahmad et al., 2003) Fusarium acuminatum (Ingle et al., 2008) and Penicillium fellutanum (Kathiresan et al., 2009).

The aim of this study is to evaluate the bioinsecticidal effect of silver nanoparticles synsthized by soil fungus (Fusarium oxysporum) (Fo AgNPs), Bacillus thuringiensis $(B t)$ and propolis extracts against Tetranychus urticae Koch and Tetranychus cinnabarinus (Boisduval).

\section{MATERIALS AND METHODS}

\section{Microbial Strains}

Bacillus thuringiensis (4QSTR1) was obtained from Bacillus Genetics Stock Center, Biochem. Dept., Ohio Univ., Columbus, USA. Bacillus thuringiensis was maintained on Luria-Bertani (LB) medium, containing: $1 \%$ tryptone, $0.5 \%$ yeast extract and $0.5 \% \mathrm{NaCl}$ and $\mathrm{pH}$ 7.0 (Sambrook et al., 1989).

\section{Separation of Crystals and Endospores}

Bacillus thuringiensis was grown in petri dishes. The spores were collected from L.B agar plates then washed thrice with ice-cold distilled water. Pellets (spores and crystals) were resuspended in small volumes of distilled water. The bacterial crystals and endospores were prepared according to the method previously described by Karamanlidou et al. (1991).

Staining crystal toxin of Bacillus thuringiensis

Samples were prepared for microscopic examination according to (Wu and Chang, 1985).

\section{Silver nanoparticles synthesized using $F$. oxysporum}

Silver nanoparticles synthesized by $F$. oxysporum (Fo-AgNPs) were used in this investigation. The $F_{O}$ AgNPs were obtained in a previous study by Sabrien and Dawood, (2016). These silver nanoparticles appeared as polydisperesed spherical particles characterized by being stable in solutions and ranging in size from 9-24 nm.

\section{HPLC separation of flavonoids and phenolic compounds}

HPLC analysis was conducted in the laboratories of Food Science and Technology institue, Giza, Egypt. An Agilent 1100 HPLC system (Agilent Technologies, Palo Alto, CA, USA) was used to identify and quantify the flavonoids and phenols of propolis (Shuai et al., 2014).

\section{Preparation of propolis extracts.}

Propolis used in this work was collected and then kept in the dark until processing. The procedure described by. Alencar et al., (2007) with some modification. Twenty grams of fine ground propolis was added to different solvents (ethanol $95 \%$ and water) to a final volume $100 \mathrm{~mL}$. The mixtures were protected from light, with moderate shaking during $24 \mathrm{~h}$, at room temperature and left at rest overnight, these mixtures were filtered through Whatman filter paper No.1. These mixtures were ethanolic extract of propolis (EEP) and water extract of propolis (WEP).

Target mites: Adult female of carmine spider mite, Tetranychus cinnabarinus (Boisduva) and the two spotted spider mite, Tetranychus urticae Koch. (Acari: Tetranychidae.) were collected from unsprayed castor bean plants and reared at $25 \pm 2^{\circ} \mathrm{C}$ and $60 \pm 5 \% \mathrm{RH}$ in laboratory of Plant Protection Research Institute, Agriculture Research Center.

Bioassay test: To assess the activity of bioniscticides (Bacillus thuringiensis, silver nanoparticles and propolis) against adult females of $T$. cinnabarinus and T. urticae. Thirty newly emerged adult females were transferred to the lower surface of castor leave discs $(2.5$ $\mathrm{cm}$ diameter) placed separately on moist cotton wool in petri dishes. Each petri dish contains three replicates, ten individuals in each replicate. Each acaricide had four concentrations which were sprayed on the individuals.Mortality was examined 1, 3, 5 and 7 days after treatment. The mortality percentage was estimated and corrected according to the Abbott's formula (1925). $\mathrm{LC}_{50}$ values were determined using probit analysis statistical method of Finney (1971).

Equation: Sun (1950) (to determine $\mathrm{LC}_{50}$ index) Toxicity index for LC $50=\frac{\text { LC50 of the most effective compฐund }}{\text { LC50 of the least effective compound }}$ X 100

\section{RESULTS AND DISCUSSION}

To confirm that $B$. thuringiensis (4QSTR1) produced cry proteins, light microscopy and Coomassie staining of spore-crystal mixtures were used. Cry protein appeared as stained crystals (Fig. 1). Coomassie Brilliant Blue stain allowed a rapid and high productivity assessment of $B$. thuringiensis (4QSTR1). There is a relationship between the insecticide activity and the crystal morphology of Bt (Maeda et al., 2000). Therefore, the strain was examined for crystal morphology. A few of the crystals did not staining well, however the differences between spores and crystals were clear enough to easily differentiate the two, even when crystal morphology mimicked that of spores (Fig. 1). The spores were appeared as dark-staining body.

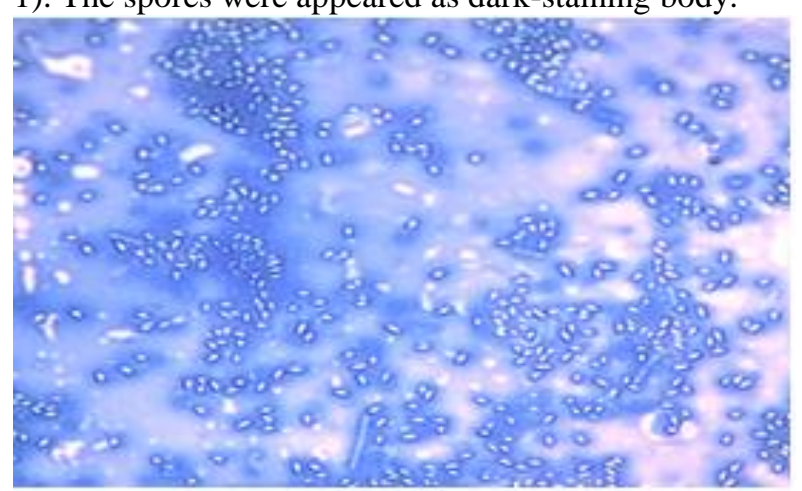

Fig. 1. Light Microscopic examination of stained sporulating culture of Bacillus thuringiensis using $100 \mathrm{x}$ lens

HPLC separation of flavonoids and phenolic compounds High-performance liquid chromatography equipped with a diode array detector was used to separate flavonoids and phenolic compound from samples with varied matrixes. It was used to identify and quantify the flavonoids and phenolic compounds in propolis. Table 1 shows the amount $(\mu \mathrm{g} / 100 \mathrm{~g}$ of dry matter) of fifteen phenolic acids and fifteen flavonoids. The resultant appeared that chlorogenic was the most identified phenolic compound $(120.62 \mu \mathrm{g} / 100 \mathrm{~g}$ dry weight) and the acacetin was the major identified flavonoid component in propolis 
(647.53 $\mu \mathrm{g} / 100 \mathrm{~g}$ dry weights) (Shuai et al. 2014). These results can state that propolis has general biological activities as insecticides activity

Table 1. Polyphenol and flavonoid contents of propolis

\begin{tabular}{lclc}
\hline Polyphenols & $\boldsymbol{\mu g} \mathbf{~ / 1 0 0 ~} \mathbf{g}$ Flavonoids & $\boldsymbol{\mu g} \mathbf{~ / 1 0 0 ~} \mathbf{g}^{*}$ \\
\hline Pyrogallol & 11.05 & Acacetin & 647.53 \\
Gallic & 5.12 & Apigenin -7- glucose & 96.98 \\
Ellagic & 13.58 & Quercetrin & 64.19 \\
Protocatechuic & 23.91 & Rutin & 94.66 \\
Catechol & 3.51 & Hisperidin & 561.09 \\
Chlorogenic & 120.62 & Narenigin & 69.86 \\
p.coumaric & 7.05 & Quercetin & 45.64 \\
Coumarin & 8.21 & Hesperitin & 41.68 \\
Salycillic & 3.63 & Apigenin & 57.31 \\
Cinnamic & 4.85 & Kaempferol & 8.54 \\
Epicatechin & 8.13 & Rhamnetin & 11.54 \\
Caffeic & 14.32 & Naringenin & 13.23 \\
Caffeine & 19.53 & Catechin & 53.00 \\
Vanillic & 13.58 & Luteolin & 109.42 \\
Ferulic & 7.01 & Luteolin- 7 - & 11.25 \\
\hline
\end{tabular}

$* \mu \mathrm{g} / 100 \mathrm{~g}$ of dry matter

Toxicity of certain bioinsecticides against Tetranychus urticae Koch adult after seven days at $25 \pm 2 \circ \mathrm{C}$ and $65 \pm 5 \% \mathrm{RH}$.

The lethal effect of synthesized Fo Ag-NPs, B. thuringiensis and propolis extracts was investigated against adult mites Tetranychus urticae Koch in vitro (Table 2) and Fig. 2. Bioassays data appeared that the efficacy of synthesized $F_{O}$-AgNPs ( $\mathrm{LC}_{50}, 45$ and $\mathrm{LC}_{90}$ was 14 ) were more effective than water extract of propolis (WEP), ethanolic extract of propolis (EEP) and $B t\left(\mathrm{LC}_{50}, 10234 \mathrm{and}\right.$ $\left.\mathrm{LC}_{90}, 110465\right)\left(\mathrm{LC}_{50}, 12755\right.$ and $\left.\mathrm{LC}_{90}, 205649\right)$, and $\left(\mathrm{LC}_{50}, 14972\right.$ and $\left.\mathrm{LC}_{90}, 67820\right)$, respectively. More than $100 \%$ toxicity index was recorded by synthesized Fo AgNPs. The LC values of $B t$ are affected by crystal protein and geographical variation of the parental $B t$ strain. These results agreed with Subarani et al. (2013) who found that the maximum efficacy was achieved by using synthesized AgNPs against the fourth instar larvae of Anopheles stephensi $\left(\mathrm{LC}_{50}, 12.47\right.$ and $16.84 \mathrm{mg} / \mathrm{mL}$; and $\mathrm{LC}_{90}, 36.33$ and $68.62 \mathrm{mg} / \mathrm{mL}$ ) in 48 and $72 \mathrm{~h}$ of exposure and against Culex quinquefasciatus $\left(\mathrm{LC}_{50}, 43.80 \mathrm{mg} / \mathrm{mL}\right.$; and $\mathrm{LC}_{90}$, $120.54 \mathrm{mg} / \mathrm{mL}$ ) in 72-h exposure. Soni and Prakash (2013) who examined the insecticidal effect of AgNPs synthesized by Aspergillus niger against larvae and pupae of Aedes aegypti and found that the efficacy $\mathrm{LC}_{50} 4$ and $\mathrm{LC}_{90} 12$ ppm. Sinha et al. (2009) reported that the silver nanoparticles synthesized by biological methods have many advantages over chemical and physical methods. Recently, Salunkhe et al. (2011) studied the larvicidal potential of AgNPs synthesized using fungus, Cochliobolus lunatus, against Aedes aegypti and Anopheles stephensi. On the other hands, (Aronson et al. 1991) showed the effect of different B. thuringiensis strains on Spodoptera littoralis and found great variability in toxicities depending on the insects that were fed crystals, solubilized crystals or in vitro activated crystals).

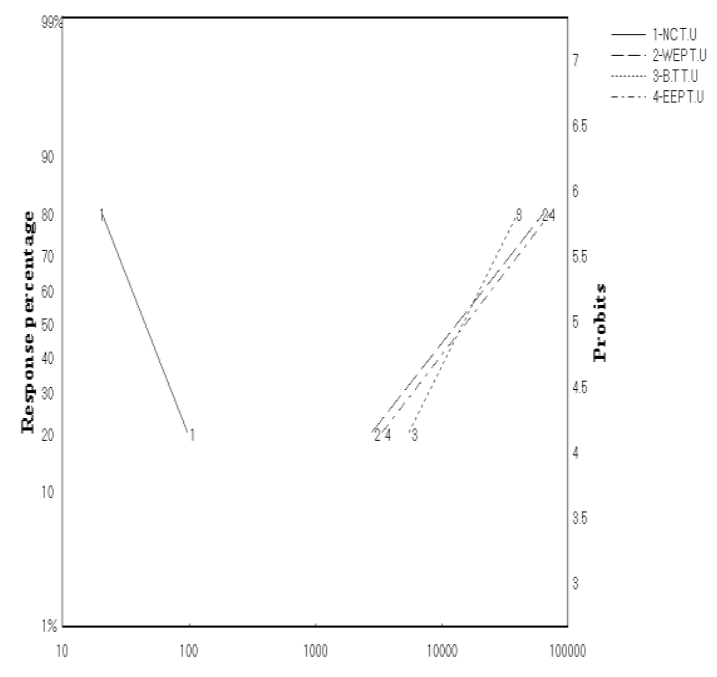

Fig. 2. log concentration probit lines showing Lethal cocncentration of bioinsecticides - against adult female of Tetranychus urticae Koch.

Table 2. Efficiency of Lethal concentration of bioinsecticides against two spotted spider mite, Tetranychus urticae Koch after seven days at $25 \pm 2 \circ \mathrm{C}$ and $65 \pm 5 \% \mathrm{RH}$.

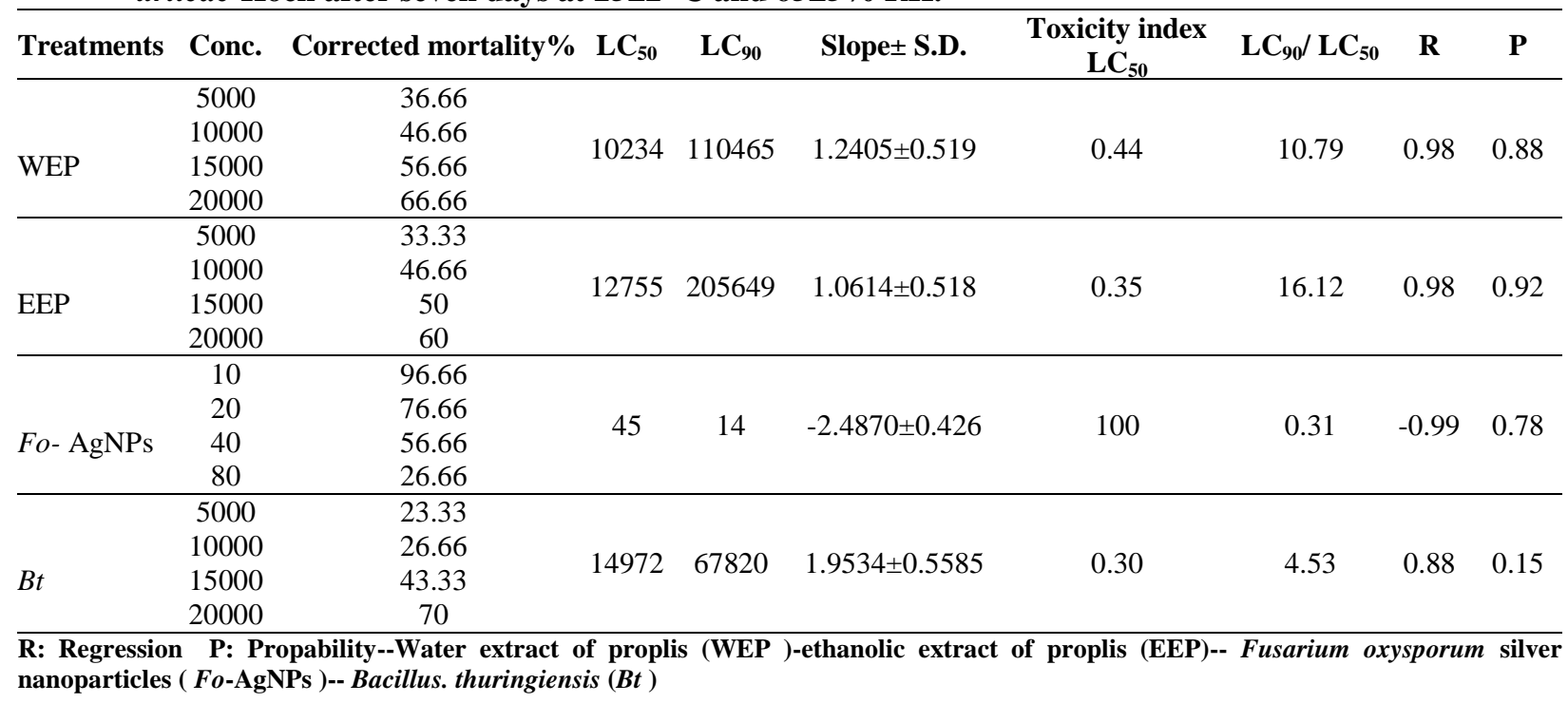


The effect of bioinsecticides against two spotted spider mite, Tetranychus urticae Koch. at 25 $\pm 2 \circ \mathrm{C}$ and $65 \pm 5 \%$ RH.

In the present study, the presented data in Table 3 appeared that the highest mortility proportion $(96.66 \%)$ was obtained at the lowest dose (10 ppm) of $F o$-AgNPs after 7 days, Meanwhile, at the highest dose $\left(20 \times 10^{3}\right.$ ppm) of $B t$-bioinsectcide the highest mortility proportion was (70\%) after 7 days. On the other side, by using WEP and EEP at dose $\left(20 \times 10^{3} \mathrm{ppm}\right)$, the highest mortility proportion was $(66.66,60 \%)$, respectively after 7 day. The total mortality percentage was more affected by $F_{o}-\mathrm{AgNPs}$ at the lowest dose (10 ppm). Whereas, the propolis extracts and $B t$ were more effective at the highest dose $\left(20 \times 10^{3} \mathrm{ppm}\right)$. The obtained results supported that the biosynthesized $\mathrm{Fo}_{\mathrm{O}}$ AgNPs had a strong insecticidal effect. The results agreed with Jalalizand et al. (2013) who found that significant mortality effect of silver nano particles at different concentrations of 2.5, 5, 10, 50, 100, 200, 500, 1000, 2000 and $3000 \mathrm{ppm}$ on adult mites. Whereas, Chapman and Marjorie (2009) found that different concentrations of Bacillus thuringiensis var. tenebrionis caused less mortality on adult females of T. urticae but had more toxicity to Metaseiulus occidentalis females at 48 h. Female T. urticae exhibited $90.0 \pm 14.2 \%$ survival vs. $26.0 \pm 23.4 \%$ survival for Metaseiulus occidentalis Nesbittis at the field rate. The significantly increased mortality was obtained when the female predators were starved for $24 \mathrm{~h}$ prior to treatment with Btte wettable powder.
Table 3. Corrected mortality \% of bioinsecticides against two spotted spider mite, Tetranychus urticae Koch under laboratory conditions $25 \pm 2 \cdot \mathrm{C}$ and $65 \pm 5 \%$ RH.

\begin{tabular}{|c|c|c|c|c|c|c|}
\hline \multirow[b]{2}{*}{ No. } & \multirow[b]{2}{*}{ Treatments } & \multirow[b]{2}{*}{$\begin{array}{l}\text { Conc. } \\
\text { (ppm) }\end{array}$} & \multicolumn{4}{|c|}{ Mortality after treatments \% } \\
\hline & & & $\begin{array}{l}\text { One } \\
\text { day }\end{array}$ & $\begin{array}{l}\text { Three } \\
\text { days }\end{array}$ & $\begin{array}{l}\text { Five } \\
\text { days }\end{array}$ & $\begin{array}{c}\text { Seven } \\
\text { days }\end{array}$ \\
\hline \multirow{4}{*}{1} & \multirow{4}{*}{ WEP } & 5000 & ---- & 16.67 & 30 & 36.66 \\
\hline & & 10000 & 13.33 & 23.33 & 36.33 & 46.66 \\
\hline & & 15000 & 20 & 26.67 & 40 & 56.66 \\
\hline & & 20000 & 26.67 & 33.33 & 53.33 & 66.66 \\
\hline \multirow{4}{*}{2} & \multirow{4}{*}{ EEP } & 5000 & ---- & 16.67 & 20 & 33.33 \\
\hline & & 10000 & 3.33 & 13.33 & 30 & 46.66 \\
\hline & & 15000 & 13.33 & 20 & 33.33 & 50 \\
\hline & & 20000 & 20 & 23.33 & 43.33 & 60 \\
\hline \multirow{4}{*}{3} & \multirow{4}{*}{ Fo- AgNPs } & 10 & 3.33 & 53.33 & 93.33 & 96.66 \\
\hline & & 20 & 33.33 & 40 & 53.33 & 76.66 \\
\hline & & 40 & 36.66 & 39.66 & 46.33 & 56.66 \\
\hline & & 80 & ---- & 13.33 & 23.33 & 26.66 \\
\hline \multirow{4}{*}{4} & \multirow{4}{*}{$B t$} & 5000 & --- & ---- & 3.33 & 23.33 \\
\hline & & 10000 & ---- & ----- & 10 & 26.66 \\
\hline & & 15000 & 20 & 33.33 & 36.66 & 43.33 \\
\hline & & 20000 & 10 & 10.0 & 43.33 & 70 \\
\hline 5 & $\begin{array}{c}\text { Control } \\
\text { (Distilled water) }\end{array}$ & & 0 & 0 & 0 & 0 \\
\hline
\end{tabular}

Water extract of proplis (WEP )-ethanolic extract of proplis (EEP)-- Fusarium oxysporum silver nanoparticles ( Fo-AgNPs )-Bacillus. thuringiensis $(B t)$

The lethal effect of synthesized Fo-AgNPs, $B$. thuringiensis and propolis was investigated against adult mites, Tetranychus cinnabarinus (Boisduval) in vitro (Table 4 and Fig. 3). Bioassays results showed that the efficacy $\left(\mathrm{LC}_{50}\right.$ and $\mathrm{LC}_{90}$ ) of Fo-AgNPs (37 and 6.554) was more effective than WEP, EEP and $B t$ (13579 and 146880.6), (15881and 164125) and (17003 and 81996.7), respectively.

Table 4. Efficiency of certain bioinsecticides against carmin spider mite, Tetranychus cinnabarinus (Boisduval). after seven days at $25 \pm 2 \circ \mathrm{C}$ and $65 \pm 5 \%$ RH.

\begin{tabular}{|c|c|c|c|c|c|c|c|c|c|}
\hline Treatments & Conc. & $\begin{array}{c}\text { Corrected } \\
\text { mortality \% }\end{array}$ & $\mathbf{L C}_{50}$ & $\mathbf{L C}_{90}$ & Slope \pm S.D. & $\begin{array}{c}\text { Toxicity index } \\
\text { LC }_{50}\end{array}$ & $\begin{array}{l}\mathbf{L C}_{90} / \\
\mathbf{L C}_{50}\end{array}$ & $\mathbf{R}$ & $\mathbf{P}$ \\
\hline \multirow{4}{*}{ WEP } & 5000 & 30 & \multirow{4}{*}{13579} & \multirow{4}{*}{146880.6} & \multirow{4}{*}{$1.2394 \pm 0.5235$} & \multirow{4}{*}{0.270} & \multirow{4}{*}{10.81} & \multirow{4}{*}{0.9920} & \multirow{4}{*}{0.9531} \\
\hline & 10000 & 43.33 & & & & & & & \\
\hline & 15000 & 50 & & & & & & & \\
\hline & 20000 & 60 & & & & & & & \\
\hline \multirow{4}{*}{ EEP } & 5000 & 26.66 & \multirow{4}{*}{15881} & \multirow{4}{*}{164125} & \multirow{4}{*}{$1.264 \pm 0.5292$} & \multirow{4}{*}{0.230} & \multirow{4}{*}{10.334} & \multirow{4}{*}{0.9931} & \multirow{4}{*}{0.9576} \\
\hline & 10000 & 40 & & & & & & & \\
\hline & 15000 & 46.66 & & & & & & & \\
\hline & 20000 & 56.66 & & & & & & & \\
\hline \multirow{4}{*}{ Fo- AgNPs } & 10 & 80 & \multirow{4}{*}{37} & \multirow{4}{*}{6.554} & \multirow{4}{*}{$-1.7157 \pm 0.3786$} & \multirow{4}{*}{100} & \multirow{4}{*}{0.179} & \multirow{4}{*}{-0.9766} & \multirow{4}{*}{0.5802} \\
\hline & 20 & 70 & & & & & & & \\
\hline & 40 & 53.33 & & & & & & & \\
\hline & 80 & 23.33 & & & & & & & \\
\hline \multirow{4}{*}{$B t$} & 5000 & 20 & \multirow{4}{*}{17003} & \multirow{4}{*}{81996.7} & \multirow{4}{*}{$1.876 \pm 0.5654$} & \multirow{4}{*}{0.215} & \multirow{4}{*}{4.8225} & \multirow{4}{*}{0.9181} & \multirow{4}{*}{0.3371} \\
\hline & 10000 & 26.66 & & & & & & & \\
\hline & 15000 & 40 & & & & & & & \\
\hline & 20000 & 63.33 & & & & & & & \\
\hline
\end{tabular}

As shown from the results presented in Table 5 showed that mortality rates at the concentration of bioinsecticides were ranged between; 20 to $80 \%$ when Tetranychus cinnabarinus adult were treated with bioinsecticides. Thus, mortality was gradually increased to a maximum of 70,80 when used low concentration of bioinsecticide $F_{O}-$ AgNPs at concentrations 20 and 10 ppm, respectively. The Bt-bioinsecticide appeared the hight mortality percentage recorded $(63 \%)$ at high concentration $20 \times 10^{3} \mathrm{ppm}$. In addition, the bioinsecticide $F o$-AgNPs $(10 \mathrm{ppm})$ recorded the highest mortility $(80 \%)$ after 7 days, whereas, the 
mortality percentage of highest dose of $B T-$ bioinsectcide $\left(20 \times 10^{3} \mathrm{ppm}\right)$ was recorded $(46.66 \%)$ after 5 days, and the mortality percentage of WEP and $\operatorname{EEP}\left(20 \times 10^{3} \mathrm{ppm}\right)$ were recorded ( 43.33 and 23.32 $\%)$, respectively after 5 days. The results in agreed with Stadler et al., (2010) described the insecticidal effect of alumina nanoparticles on Sitophilus oryzae and Rhyzopertha dominica (Fabricius). Whereas, Mohan and Gujar (2003) reported that the differences in sensitivity of two populations of the diamondback moth, Plutella xylostella L to B. thuringiensis Cry1Ab were not due to midgut proteolytic activity. Further, the proteolytic patterns of Cry1A protoxins were equal in the resistant as well as sensitive populations of $P$. xylostella.

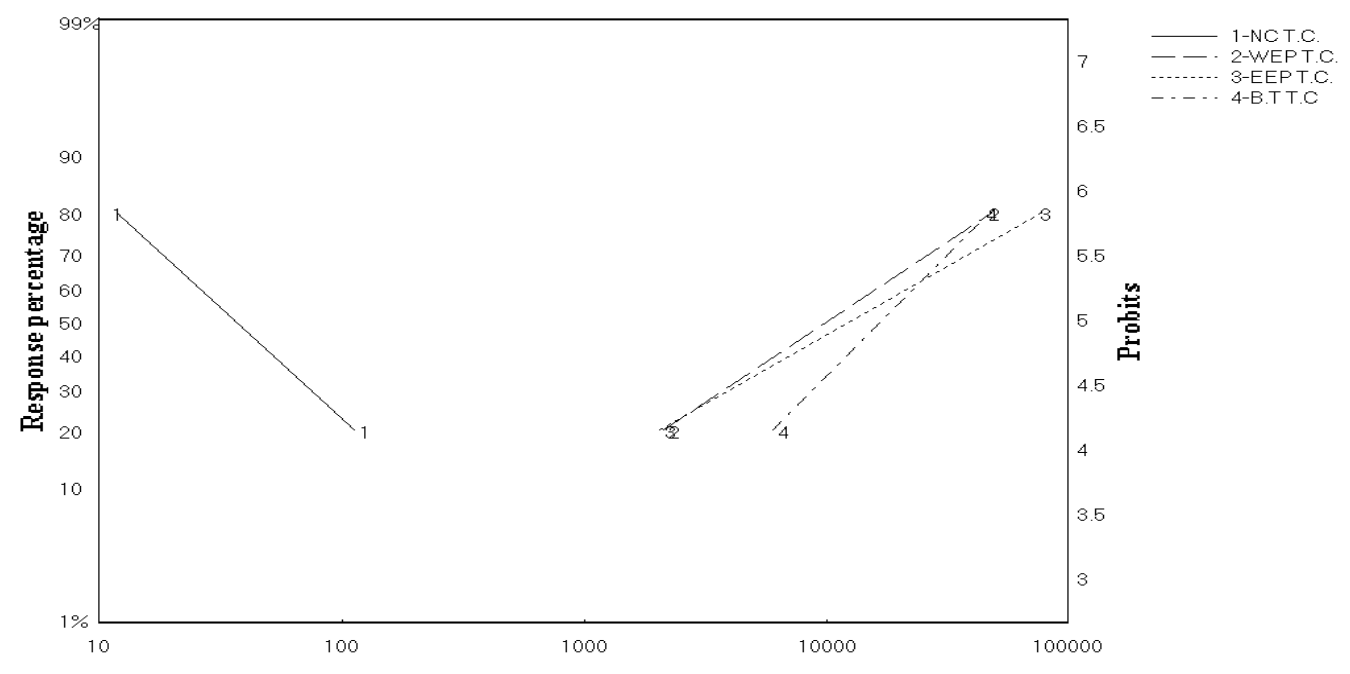

Fig. 4. log concentration probit lines showing Lethal concentration of bioinsecticides against adult female of T. cinnabarinus (Boisduval)

Table 5. Mortality rates of different concentrations of bioinsecticides against carmin spider mite, Tetranychus cinnabarinus (Boisduval) at $25 \pm 2 \circ \mathrm{C}$ and $65 \pm 5 \%$ RH.

\begin{tabular}{|c|c|c|c|c|c|c|}
\hline \multirow[b]{2}{*}{ No. } & \multirow[b]{2}{*}{ Treatments } & \multirow[b]{2}{*}{$\begin{array}{l}\text { Conc. } \\
\text { (ppm) }\end{array}$} & \multicolumn{4}{|c|}{ Mortality after treatments $\%$} \\
\hline & & & $\begin{array}{l}\text { One } \\
\text { day }\end{array}$ & $\begin{array}{l}\text { Three } \\
\text { days }\end{array}$ & $\begin{array}{l}\text { Five } \\
\text { days }\end{array}$ & $\begin{array}{c}\text { Seven } \\
\text { days }\end{array}$ \\
\hline \multirow{4}{*}{1} & \multirow{4}{*}{ WEP } & 5000 & --- & 13.33 & 20.33 & 30 \\
\hline & & 10000 & 10 & 23.33 & 33.33 & 43 \\
\hline & & 15000 & 6.66 & 19.99 & 29.99 & 50 \\
\hline & & 20000 & 10 & 23.33 & 43.33 & 60 \\
\hline \multirow{4}{*}{2} & \multirow{4}{*}{ EEP } & 5000 & --- & 6.66 & 13.33 & 27 \\
\hline & & 10000 & --- & 3.33 & 16.66 & 40 \\
\hline & & 15000 & --- & 3.33 & 33.33 & 46 \\
\hline & & 20000 & --- & 6.66 & 23.32 & 57 \\
\hline \multirow{4}{*}{3} & \multirow{4}{*}{ Fo- AgNPs } & 10 & 6.66 & 26.66 & 43.32 & 80 \\
\hline & & 20 & 6.66 & 26.66 & 43.32 & 70 \\
\hline & & 40 & 30 & 30 & 43.33 & 53 \\
\hline & & 80 & --- & 10 & 20.0 & 23 \\
\hline \multirow{4}{*}{4} & \multirow{4}{*}{$B t$} & 5000 & --- & --- & 6.66 & 20 \\
\hline & & 10000 & ---- & ---- & 13.33 & 27 \\
\hline & & 15000 & 13.33 & 19.99 & 23.32 & 40 \\
\hline & & 20000 & 13.33 & 16.66 & 46.66 & 63 \\
\hline
\end{tabular}

$5 \quad \begin{array}{ccccc}\text { Control } & & & & \\ \text { (Distilled } & 0 & 0 & 0 & 0\end{array}$

water)

Water extract of proplis (WEP )-ethanolic extract of proplis (EEP)-- Fusarium oxysporum silver nanoparticles ( Fo-AgNPs )-Bacillus. thuringiensis (Bt)

\section{CONCLUSION}

In the present investigation, bioinsecticidal effect of Bacillus thuringiensis cry toxin, propolis extracts and silver nanoparticles synsthized by soil fungus (Fusarium oxysporum)( Fo-AgNPs) against Tetranychus urticae Koch and Tetranychus cinnabarinus (Boisduval) were studied. The results revealed that the biosynsthized silver nanoparticles would be suitable for developing a biological process and can be used successfully in IPM program to control of two Tetranychus spp.

\section{REFERENCES}

Abbott, A.W.S. 1925. A method for computing the effectiveness of an insecticide. J. Econ. Entomol. 18: 265- 277.

Ahmad, A.; Mukherjee, P., Senapati, S., Mandal, D., Khan, M.I., Kumar, R., Sastry, M. 2003. Extracellular biosynthesis of silver nanoparticles using the fungus Fusarium oxysporum. Colloid Surface B. 28:313318.

Alencar, S. M., Oldoni, T. L. C., Castro, M. L. 2007. "Chemical composition and biological activity of a new type of Brazilian propolis: red propolis," J. of Ethnopharmacol., 113(2) 278-283.

Aronson, A.I., Han, E.S., McGaughey, W., Johnson, D. 1991. The solubility of inclusion proteins from Bacillus thuringiensis is dependent upon protoxin composition and is a factor in toxicity to insects. Appl Environ Microbiol 57:981-986.

Banskota, A. H., Tezuka, Y., Kodota, S. 2001. Recent progress in pharmacological research in propolis. Phtother. Res., 15 (17): 561-571

Banu, A.N., Balasubramanian, C., Moorthi, P.V. 2014. Biosynthesis of silver nanoparticles using Bacillus thuringiensis against dengue vector, Aedes aegypti (Diptera: Culicidae)," Parasitology Research, 113 (1); 311-316. 
Chapman, M.H. and Hoy, M. A. 2009. Relative toxicity of Bacillus thuringiensis var. tenebrionis to the two spotted spider mite (Tetranychus urticae Koch) and its predator Metaseiulus occidentalis (Nesbitt) (Acari, Tetranychidae and Phytoseiidae). Journal of Applied Entomology 111(1 - 5): 147 - 154 .

Chinnamuthu, C. R. and Murugesa Boopathi, P. 2009. Nanotechnology and Agroecosystem. Madras Agricultural Journal, 96: 17-31.

Farouk, S., Osman, M.A. 2009. Induction of resistance in common bean plants Phaseolus vulgaris L. using different plant elicitors against spider mite Tetranychus urticae Koch infestation. Journal of Agricultural Science, Mansoura University34 (12):11399-11419.

Finney, D. J. 1971. Probit Analysis, A statistical treatment of the sigmoid responsecurve 7th Ed., Cambridge Univ. Press, Cambridge, England.

Fortin, D., Beveridge, T.J.2000. Mechanistic routes to biomineral surface development. In: Biomineralization: From Biology to Biotechnology and Medical Application. Bäuerlein E (ed) WileyVCH, Weinheim, Germany, 7-24.

Frankenhuyzen, K. 2009."Insecticidal activity of Bacillus thuringiensis crystal proteins," Journal of Invertebrate Pathology, 101; 1-16.

Huang, T. K., Wang, P. M, Wu, W.T .2001. Cultivation of Bacillus thuringiensis in an airlift reactor with wire mesh draft tubes.J. Biochem. Eng., 7; 35-39.

Ingle, A., Gade, A., Pierrat, S., Sonnichsen, C., Rai, M. 2008. Mycosynthesis of silver nanoparticles using the fungus Fusarium acuminatum and its activity against some human pathogenic bacteria.Curr. Nanosci., 4:141-144

Jalalizand, A., Gavanji, S., Esfahani, J. k., Hassan, M., Besharatnejad, Emami, M. S., Larki, B. 2013. The effect of Silver nanoparticles on Tetranychus urticae. International Journal of Agriculture and Crop Sciences.

Karamanlidou, G., Lambropoulos, A.F., Koliais, S.I., Manousis, T., Ellar, D.1991. Toxicity of Bacillus thuringensis to laboratory populations of the olive fruit fly (Dacus oleae). Appl Environ Microbiol, 57: 2277-2282.

Kathiresan, K., Manivannan, S., Nabeel, M.A., Dhivya, B. 2009. Studies on silver nanoparticles synthesized by a marine fungus, Penicillium fellutanum isolated from coastal mangrove sediment. Colloids Surf B Biointerfaces 71:133-137.

Maeda, M., Mizuki, E., Nakamura, Y., Hatano, T., Ohba, M. 2000. Recovery of Bacillus thuringiensis from marine sediments of Japan. Curr. Microbiol., 40: 413-422.

Mohan M., Gujar, G. T. 2003. Characterization and comparison of midgut proteases of Bacillus thuringiensis susceptible and resistant diamondback moth (Plutellidae: Lepidoptera). J. Invertebr. Pathol. 82; 1-11.
Owolade, O. F., Ogunleti, D. O., Adenekan, M. O. 2008. Titanium Dioxide affects disease development and yield of edible cowpea. J. plant protection res. 48(3); 329-335.

Poopathi, S., De Britto, L.J., Praba, V.L., Mani, C., Praveen, M. 2014. Synthesis of silver nanoparticles from Azadirachta indica a most effective method for mosquito control. Environ Sci Pollut Res Int 22; 2956-2963.

Rouhani, M., Samih, M. A., Kalantari, S. 2012. Insecticidal effect of silica and silver nanoparticle . J. Entomological Research, 4 (4); 297-305.

Salomão, K., Dantas, A.P., Borba, C.M., Campos, L.C., Machado, D.G., Aquino Neto, F.R., de Castro, S.L. 2004. Chemical composition and microbicidal activity of extracts from Brazilian and Bulgarian propolis. Lett. Appl. Microbiol38, 87-92.

Sabrien, A. O., Dawood, H. D. 2016. Using soil fungus, Fusarium oxysporum for green synthesisof silver nanoparticles and evaluation of their antimicrobial effects. J. Agric. Chem., Biotech., Mansoura Univ. 7(11) ; 275-281.

Salunkhe, R.B, Patil, S.V, Salunke, B.K. 2011. Larvicidal potential of silver nanoparticles synthesized using fungus, Cochliobolus lunatus against Aedes aegypti (Linnaeus) and Anopheles stephensi Liston (Diptera: Culicidae). Parasitol Res 109; 823-831.

Sambrook, J., Fritsch, E.F., Maniatis, T. 1989. Molecular cloning: a laboratory manual, vol. 3. Cold Spring Harbor Laboratory Press, Cold Spring Harbor, N.Y.

Santhosh, S.B., Ragavendran, C., Natarajan, D. 2015. Spectral and HRTEM analyses of Annona muricata leaf extract mediated silver nanoparticles and its Larvicidal efficacy against three mosquito vectors Anopheles stephensi, Culex quinquefasciatus and Aedes aegypti. J Photochem Photobiol B. 153; 184-190.

Schünemann, R., Knaak, N., Lidia, M., Fiuza. 2014. Mode of action and Specificity of Bacillus thuringiensis toxins in the control of caterpillars and stink bugs in soybean culture. International Scholarly Research Notices. Article ID 135675.

Selvi, K.V., Sivakumar, T. 2012. Isolation and characterization of silver nanoparticles from Fusarium oxysporum. Int.J.Curr.Microbiol.App.Sci. 1, 1, 56-62.

Shuai, H., Cui-Ping, Z., Kai, W., George, Q. L., Fu-Liang, H. 2014. Recent Advances in the Chemical Composition of Propolis. Molecules.19;1961019632.

Siegel, P .2001. The mammalian safety of Bacillus thuringiensis-based insecticides. J Invertebr Pathol., 77(1);13-21.

Sinha, S., Pan, I., Chanda, P., Sen S.K .2009. Nanoparticles fabrication using ambient biological resources. J Appl Biosci 19:1113-1130 
Soni, N., Prakash, S. 2013. Possible Mosquito Control by Silver Nanoparticles Synthesized by Soil Fungus (Aspergillus niger 2587). Advances in Nanoparticles. 2:125-132.

Stadler, T., Butelerb, M., Weaver, D. K. 2010. Novel use of nanostructured alumina as an insecticide. Pest Management Science, 66: 577579.

Subarani, S., Sabhanayakam, S., Kamaraj, C. 2013. Studies on the impact of biosynthesized silver nanoparticles (AgNPs) in relation to malaria and filariasis vector control against Anopheles stephensi Liston and Culex quinquefasciatus Say (Diptera: Culicidae). Parasitol Res 112: 487-499.

Sun, Y. P. 1950. Toxicity index - An Improved method of comparing the relative toxicity of insecticides. J. Econ. Entomol., 43 (1): 45-53.

Thomas, D.J., Morgan, J.A., Whipps, J.M., Saunders, J.R. 2000. Plasmid transfer between the Bacillus thuringiensis subspecies kurstaki and tenebrionis in laboratory culture and soil and in lepidopteran and coleopteran larvae. Appl Environ Microbiol; 66:118-24.
Vahabi, K., Mansoori, G.A. and Karimi, S. 2011. Biosynthesis of silver nanoparticles by fungus Trichoderma reesei (A Route for Large-Scale Production of AgNPs). Insciences J., 1(1); 65-79.

Vance, C.P. 1998. Legume symbiotic nitrogen fixation: agronomic aspects. In The Rhizobiaceae. Molecular Biology of Model Plant-Associated Bacteria, pp. 509-530. Eds.

Wu, D., Chang, F. 1985. Synergism in the mosquitocidal activity of 26 and $65 \mathrm{kDa}$ proteins from Bacillus thuringiensis subsp. Fukuokaensis crystal proteins. Appl Environ Microbiol. 57: 1075-1081.

Yang J., Kloepper, J.W., Ryu, C.M. 2009. Rhizosphere bacteria help plants tolerate abiotic stress. Trends in Plant Science, 14, 1-4.

Zewdu, A., Gemechis, L. 2016. Insecticidal action of honeybees propolis extract against larvae of lesser wax moth. Agric., Biol., J of North Amrica, 7 (6); 302-306.

Zhang, Z. Q. 2003. Mites of greenhouses: identification, biology and control. Cabi Publishing, Wallingford, 244.

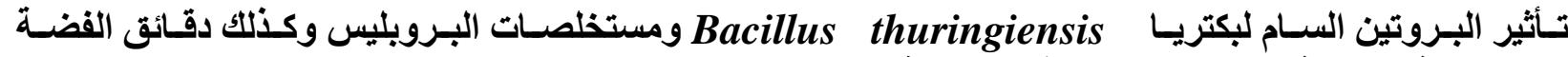

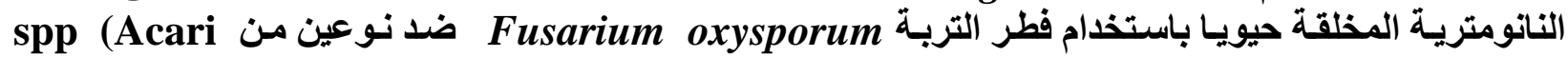 Tetranychus :Tetranychidae )

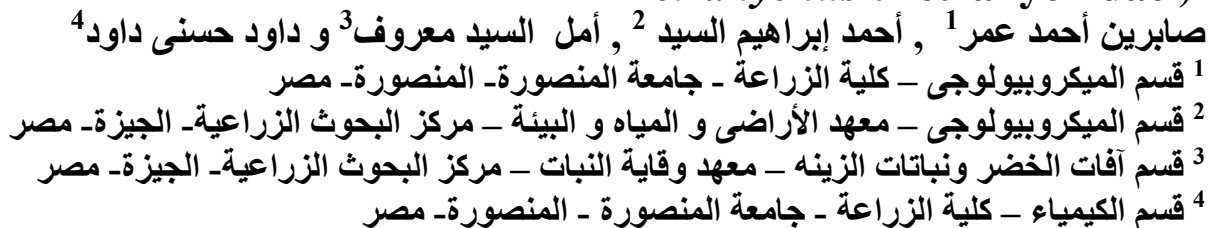

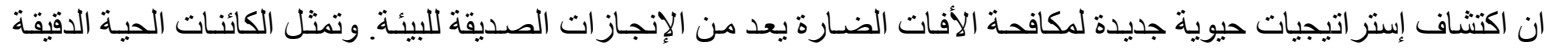

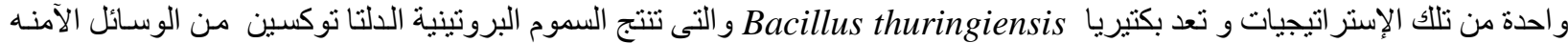

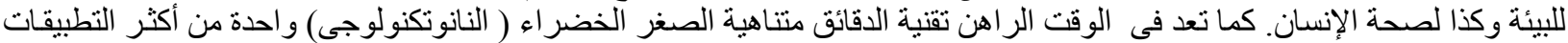
الو اعدة فى هذا المجال. ومن هذه الدر اسة ظهرت فئ قدرة Bacillus thuringiensis على إنتاج البروتين الكريستالى السام باستخدام صبغة

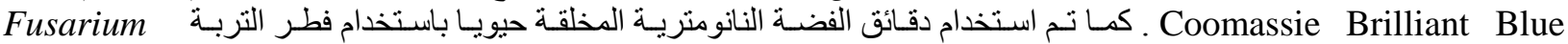
oxysporum

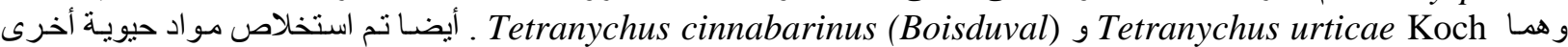

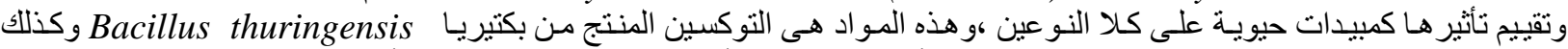

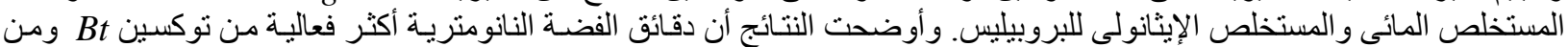

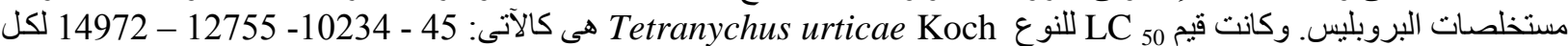

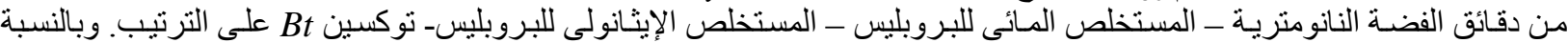

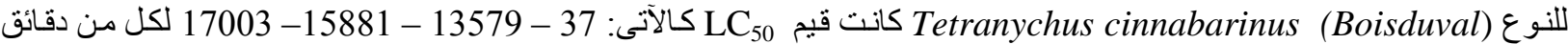

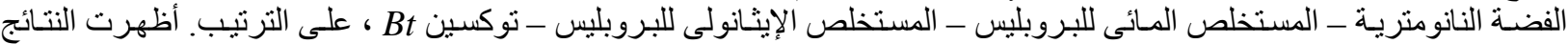

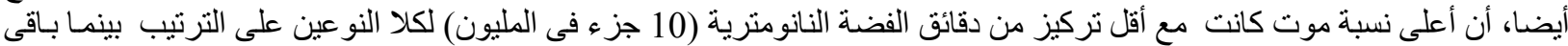

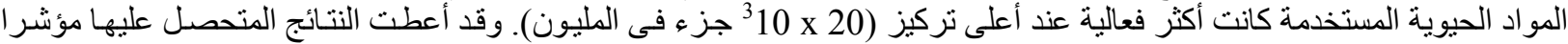
على أن دقائق الفضة النانومترية المخلقة حيويا من فطر التربة Fusarium oxysporum مبيدات حيوية أكثر فعالية. 